Revista Brasileira de Cartografia

ISSN 1808-0936 | https://doi.org/10.14393/revbrascartogr

Sociedade Brasileira de Cartografia, Geodésia, Fotogrametria e Sensoriamento Remoto

\title{
Os Hidrônimos Catuenses e suas Marcas no Território
}

\section{Catuenses Hydronyms and their Brands in the Territory}

\author{
Adriana Andrade Arnaut ${ }^{1,2}$ e Luciano Lourenço ${ }^{2}$
}

1 Instituto Federal de Educação, Ciência e Tecnologia Baiano, Campus Catu, Catu, Brasil. E-mail. adriana.arnaut@ifbaiano.edu.br ORCID: https://orcid.org/0000-0002-9060-6879

2 Universidade de Coimbra, Departamento de Geografia e Turismo, Coimbra, Portugal. E-mail. luciano@uc.pt

ORCID: https://orcid.org/0000-0002-2017-0854

Resumo: Os topônimos designam acidentes naturais e culturais presentes no espaço geográfico. Os hidrônimos topônimos relacionados à rede hidrográfica - podem carregar características relacionadas à origem da população e às diferentes fases da ocupação do território. A cartografia histórica é um meio de resgate da toponímia de uma região. Assim, este trabalho objetivou identificar, listar e classificar os hidrônimos do município de Catu-Bahia, Brasil, através de documentos da cartografia histórica, verificando quais foram as influências desses topônimos na ocupação do território catuense, contribuindo com a história local do município. Para isto, utilizaram-se três documentos cartográficos de períodos distintos: séculos XIX (1888), XX (1939) e XXI (2018). Destaca-se à preponderância das línguas indígena e portuguesa nos nomes dos elementos hidrográficos, sendo a classe dos Fitotopônimos, a mais presente entre estas denominações. Os mapas e planta analisados neste trabalho proporcionaram visualização da configuração espacial dos acidentes naturais e culturais do período em que foram cartografados. Nota-se que componentes da formação territorial, tais como cidade, vila, povoados e fazendas instalaram-se próximos aos elementos hidrográficos e, alguns, assumiram as nomenclaturas destes, dada a importância da hidrografia para a população.

Palavras-chave: Hidrônimo. Toponímia. Cartografia Histórica. Território.

\begin{abstract}
Place names designate natural and cultural accidents present in the geographic space. Hydronyms toponyms related to the hydrographic network - can carry characteristics related to the origin of the population and the different phases of occupation of the territory. Historical cartography is a means of rescuing a region's toponymy. Thus, this work aimed to identify, list and classify the hydronyms of the municipality of Catu-Bahia, Brazil, through documents of historical cartography, verifying what were the influences of these toponyms in the occupation of the territory of Catu, contributing to the local history of the municipality. For this, three cartographic documents from different periods were used: XIX (1888), XX (1939) and XXI (2018) centuries. The preponderance of the indigenous and Portuguese languages in the names of the hydrographic elements stands out, being the class of Phytotoponyms, the most present among these denominations. The maps and plants analyzed in this work provided visualization of the spatial configuration of the natural and cultural accidents of the period in which they were mapped. It is noted that components of territorial formation, such as city, town, settlements and farms were installed close to the hydrographic elements and, some, assumed their nomenclatures, given the importance of hydrography.
\end{abstract}

Keywords: Hydronym. Toponymy. Historical Cartography. Territory.

\section{INTRODUÇÃO}

Dentre os elementos simbolizados em um mapa, encontram-se os topônimos. Segundo o IBGE (2011), "o topônimo é concebido como a denominação de acidentes naturais e culturais que são representados em documentos cartográficos, em diversas escalas”. Em suma, topônimo é o nome do lugar.

Os topônimos podem ajudar a entender a identidade histórica e a descrição geográfica de um lugar. O seu estudo permite fundamentar e aprimorar o conhecimento a respeito da ocupação territorial, das pessoas 
que ali viviam, do ambiente físico, bem como resgatar aspectos culturais, políticos, sociais, ideológicos, entre outros.

O estudo toponímico utilizando a cartografia histórica vem crescendo bastante, pois o mapa histórico é um registro temporal, detentor de elementos da época em que foi cartografado. Yeginbayeva et al. (2016, p. 12, tradução nossa) afirmam que "Os mapas geográficos contêm muitas informações valiosas sobre dados históricos que tornam possivel definir a grafia da toponímia e a sua localização" . A extração dos topônimos existentes nos mapas históricos e a organização desses nomes referentes a um mesmo lugar, através de uma escala temporal, fazem com que o estudo da toponímia tenha uma relação direta com a cartografia histórica. A cartografia "[...] assume o papel de tornar-se o registro e a certidão de nascimento das feições geográficas, que marcam a passagem do homem sobre a superficie de nosso planeta" (MENEZES; SANTOS; SANTOS, 2010).

Diversas abordagens já foram apresentadas para o estudo geral da toponímia, com foco para o resgate e o registro cultural, histórico e social de uma região. Como definiu Ferro (1979, p. 128) a toponímia "é um testemunho da presença do homem num certo espaço, ao longo do tempo".

Pôde-se observar que, nos estudos existentes sobre topônimos, existe uma tendência para pesquisar a sua origem linguística, buscando a motivação para a escolha do nome próprio do lugar, bem como a sua análise histórica e cultural, conforme afirma Silva (2019, p. 8): "Os estudos toponímicos têm sua base na Linguística e objetivam analisar as ligações existentes entre o nome e a coisa nomeada, ou seja, os fatores motivacionais, cujo topônimo torna-se motivado".

$\mathrm{O}$ ato de nomear faz com que o acidente geográfico adquira identidade, passando a fazer parte da cultura do lugar. Ferro (1979) procurou dar sua contribuição no estudo da toponímia dando aos topônimos um significado geográfico. Esse autor afirma que:

A transformação de um termo geográfico dialectal em topônimo é bastante frequente do que parece; ocorre quando o correspondente objecto geográfico adquire um particular interesse para o homem, quer ele se limite simplesmente a notar-lhe qualidade ou atributos, quer o encare como elemento favorável ou desfavorável às suas atividades (FERRO, 1979, pp. 127128).

O estudo dos nomes dos elementos hidrográficos - rios, riachos, córregos, lagoas, entre outros - é denominado hidronímia e o nome próprio destes elementos, hidrônimo. A nomenclatura desses acidentes naturais traz a característica da população que ocupou o território ao longo do tempo e, em algumas vezes, pode também sofrer mudança de nome com o passar dos anos - alteração toponímica. A partir deste fato, notase que o documento cartográfico histórico tem papel importante na recuperação do nome do lugar, pois através dele pode-se resgatar o topônimo pretérito que sofreu modificação.

Em se tratando de hidronímia, Lind (1963) reconhece em sua obra que:

O capítulo sobre os nomes dos rios, costuma ser o mais interessante da história toponímica dum país, pela antiguidade dos nomes e consequente dificuldade de interpretação. [...] designações de cores, [...] negra e branca [...]. Diferentes propriedades naturais [...] Rios Salgados e Rios Doces [...] (LIND, 1963, p. 53).

A água é um componente fundamental para a vida humana e muitas cidades foram erguidas nas proximidades de elementos hidrográficos, em especial de rios. Isquerdo e Dick (2013, n.p.) reiteram que "São também nas margens dos rios que surgem os primeiros povoados que se transformam em cidades no decurso da história". Assim, quando o rio é a gênesis de uma cidade, ele é o primeiro topônimo a ser batizado. O Rio Catú - palavra de origem indígena, cujo significado é "bom, são, conservado" (BARBOSA, 1951, p. 46) - é o topônimo do rio que cruza o território catuense no sentido norte-sul e, também, nomeia o município definido como recorte geográfico do presente trabalho.

Castiglioni (2018, p. 1098) enfatiza que os hidrônimos "[...] só produzem sentido e atribuem significado enquanto enunciado toponímico, formado por um termo genérico e um termo específico". O termo

\footnotetext{
${ }^{1}$ Geographical maps have a lot of valuable information on historical data that makes it possible to define toponymy spelling and it's location.
} 
genérico seria o nome do elemento geográfico referente a água e o termo específico, o nome próprio do elemento hidrográfico. "Não há no contexto do mapa cursos de água identificados somente por um ou outro termo" (CASTIGLIONI, 2018, p. 1098). Destaca-se, também, a importância de um termo complementar o outro, pois existem elementos hidrográficos que possuem na sua nomenclatura, nomes próprios de país, estado e localidades - a exemplo do Rio Catú.

Diante do exposto, este trabalho tem como objetivo geral identificar, listar e classificar os topônimos relacionados à rede hidrográfica - hidrônimos - do município de Catu-Bahia ${ }^{2}$, Brasil, através de documentos da cartografia histórica de períodos distintos e verificar quais as influências desses topônimos no desenvolvimento do território catuense.

Apresenta como objetivos específicos:

a) Identificar os hidrônimos a partir de documentos cartográficos, com escalas e períodos diferentes;

b) Classificar os hidrônimos de acordo com o modelo de taxionomias proposto por Dick (1992), padrão este consolidado e adequado à realidade brasileira;

c) Identificar e registrar a língua de origem dos hidrônimos, a fim de quantificar a contribuição de cada língua nas denominações dos elementos hidrográficos do município de Catu, considerando cada mapa estudado;

d) Pesquisar como os hidrônimos colaboraram na dinâmica territorial do município de CatuBahia.

A contribuição deste trabalho está em apontar a influência dos topônimos, em específico os hidrônimos, no processo de formação do território catuense. O conhecimento dos hidrônimos tem em si uma colaboração à geo-história do município, refletindo características físicas e culturais do espaço geográfico e da sociedade que ali vivia, num dado período. Assim, resgatando a origem linguística da denominação desses acidentes naturais e fazendo a associação destes com o espaço geográfico no qual estão inseridos, remete-nos a pensar no porque determinado rio, riacho ou córrego carrega tal nome.

\section{2 ÁREA DE ESTUDO}

O município de Catu-Bahia, Brasil, pertence ao território de identidade ${ }^{3}$ denominado Litoral Norte e Agreste Baiano e dista cerca de $80 \mathrm{~km}$ da Capital Salvador. Com localização geográfica aproximada entre as latitudes $12^{\circ} 14^{\prime} 07^{\prime \prime} \mathrm{S}$ e $12^{\circ} 25^{\prime} 44^{\prime \prime} \mathrm{S}$ e longitudes $38^{\circ} 16^{\prime} 23^{\prime \prime} \mathrm{W}$ e $38^{\circ} 32^{\prime} 18^{\prime \prime} \mathrm{W}$, confronta-se a norte com os municípios de Alagoinhas e Araçás, a leste com Pojuca, a sul com São Sebastião do Passé e a oeste com Teodoro Sampaio e Terra Nova (Figura 1). Atualmente, o município é formado por 3 distritos: Catu (sede), Bela Flor (antigo São Miguel) e Sítio Novo e, segundo a estimativa populacional apresentada pelo Instituto Brasileiro de Geografia e Estatística ${ }^{4}$ (IBGE) para o ano de 2020, a população total do município de Catu seria de 54.970 habitantes e área territorial de $426,955 \mathrm{~km}^{2}$.

\footnotetext{
${ }^{2}$ Vale lembrar que existe o rio e o município de Paracatu, em Minas Gerais, significando bom tamanho.

3 "Espaço físico, geograficamente definido, geralmente contínuo, caracterizado por critérios multidimensionais, tais como o ambiente, a economia, a sociedade, a cultura, a política e as instituições, e uma população com grupos sociais relativamente distintos, que se relacionam interna e externamente por meio de processos específicos, onde se pode distinguir um ou mais elementos que indicam identidade, coesão social, cultural e territorial". Disponível em: $<$ http://www.seplan.ba.gov.br/modules/conteudo/conteudo.php?conteudo=17>. Acesso em: 23 out. 2020.

${ }^{4}$ Disponível em: <https://www.ibge.gov.br/cidades-e-estados/ba/catu.html>. Acesso em: 12 dez. 2020.
} 
Figura 1 - Localização do município de Catu-Bahia.

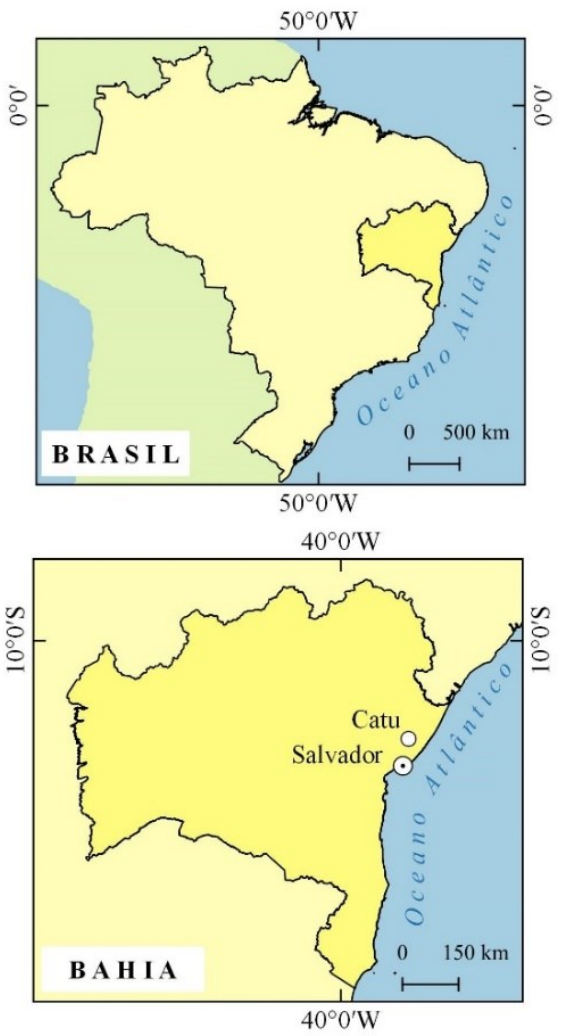

MAPA DE LOCALIZAÇÃO DE CATU-BA

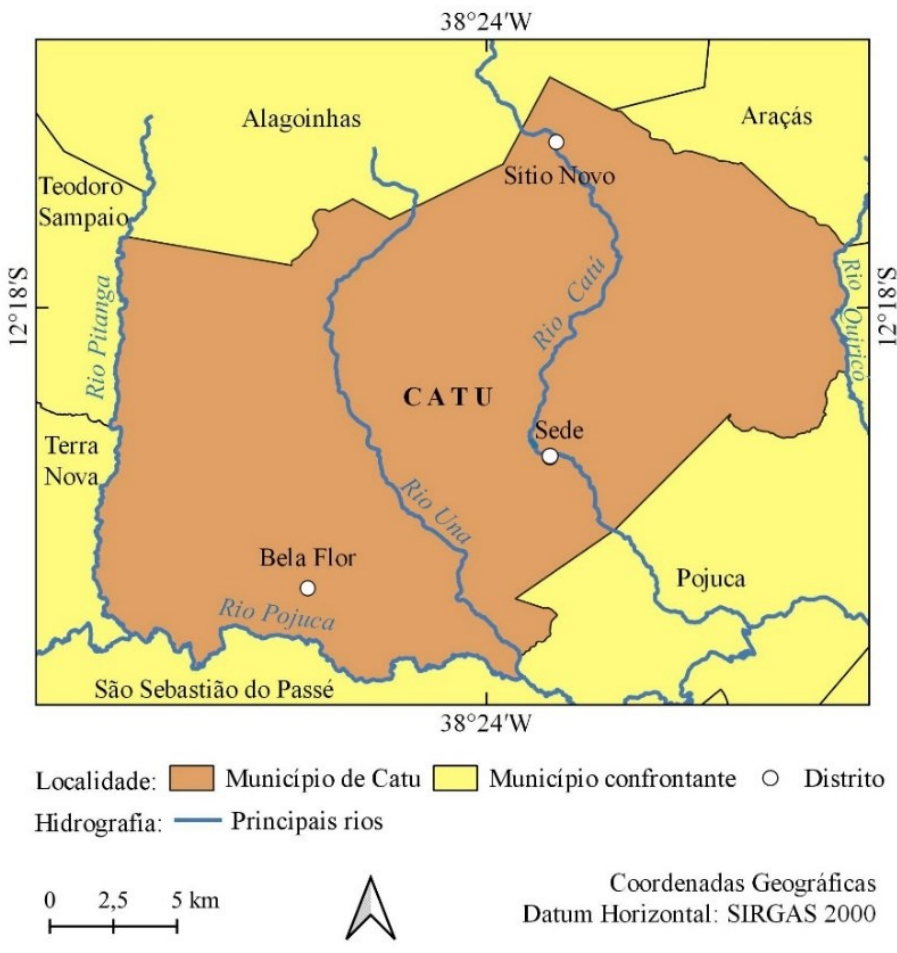

Fonte: Elaboração própria com base nos dados do IBGE (2017) e SEI/BA (2019).

Fonte: Os autores (2021).

O município faz parte da bacia hidrográfica do Recôncavo Norte, banhado pelos rios Catu, Pojuca, Una, Pitanga e Quiricó Pequeno (cf. Figura 1) e é caracterizado pelo bioma de Mata Atlântica, com constituição vegetal de floresta ombrófila em estágio inicial de regeneração, cerrado e reflorestamento ${ }^{5}$. Apresenta topografia irregular e altitude média de $100,82 \mathrm{~m}$, tomada do marco de referência de nível (RN) implantado pelo IBGE no lado esquerdo da porta principal da Igreja Nossa Senhora de Santana, igreja Matriz que é um dos primeiros marcos arquitetônicos da formação do município.

\section{A OCUPAÇÃO NAS TERRAS CATUENSES}

\section{1 Índios: primeiros habitantes}

No século XVI, quando os portugueses chegaram ao Brasil, o povo indígena habitava esta terra, agrupados em diferentes tribos, desde o litoral até o sertão ${ }^{6}$. Os índios que viviam no litoral da Bahia, embora pertencessem a nações diferentes, falavam a mesma língua: tupi.

Em toda esta província ha muitas e varias nações de differentes línguas, porem uma é a principal que comprehende algumas dez nações de índios: estes vivem na costa do mar, e em uma grande corda do sertão, porem são todos estes de uma só lingua, ainda que em algumas palavras discrepão e esta é a que entendem os Portuguezes, é fácil, e elegante, e suave, e copiosa, a difficuldade delia está em ter muitas composições (CARDIM, 1881, p. 49).

Ainda na obra de Cardim (1881, p. 51), escrita originalmente em fins do século XVI, o autor mencionou os índios "que chamão Tupinaba: estes habitão do Rio Real até junto dos Ilheos [...]”. No período colonial brasileiro, o Rio Real (Figura 2) fazia divisa entre a Capitania da Bahia e a Capitania de Sergipe Del Rey e, atualmente, demarca parte da fronteira entre os estados da Bahia e Sergipe.

\footnotetext{
${ }^{5}$ Disponível em: <http://www.inema.ba.gov.br/wp-content/files/MTematicos_vegetacao.pdf>. Acesso em: 9 dez. 2020.

${ }^{6}$ Denominação dada às terras ainda não exploradas, de difícil acesso e pouco habitadas durante o período colonial do Brasil.
} 
Os Tupinambás, Tabajaras, Potiguaras, Caetés, Tupiniquins, Tamoios e seus descendentes, mestiços com europeus e africanos, falavam a língua tupi (SAMPAIO, 1901, p. 21). O autor afirma que até o início do século XVIII, tupi, conhecida como língua geral, era a língua mais falada na colônia, proporcionalmente de três para um, em relação ao português.

A seguir um trecho do mapa Novus Brasiliae Tipus (BLAEU, 1631?) no qual assinalamos a posição aproximada em que se estabeleceu o território catuense (cf. Figura 2), local de presença da nação Tupinambá.

Figura 2 - Trecho do mapa Novus Brasiliae Tipus, com sinalização do Rio Real e Ilhéus e destaque para o local onde aproximadamente se estabeleceu o território catuense. Nota à indicação dos índios na região.

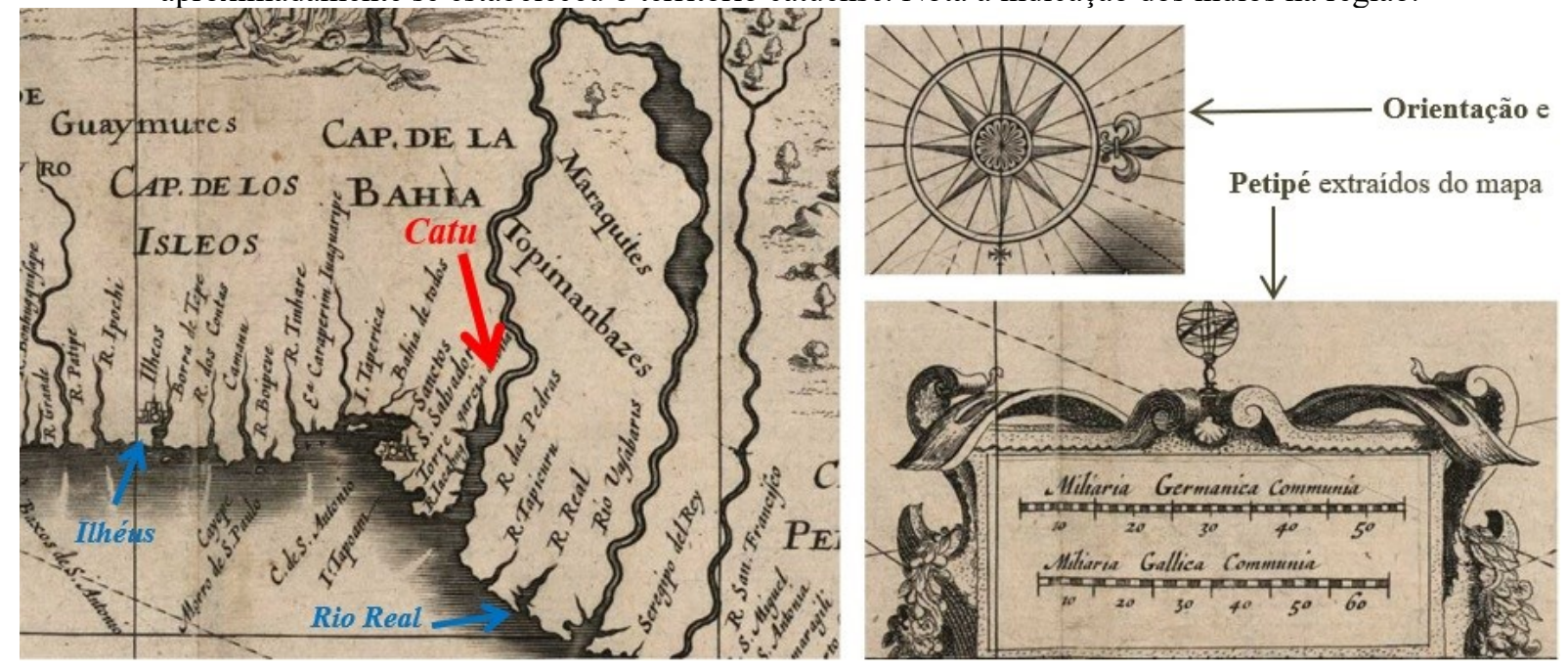

Fonte: Blaeu (1631?).

Sampaio fez referência à toponímia tupi, que é muito evidente nos acidentes geográficos naturais e culturais brasileiros, e ao resgate desses nomes após mudanças, evidenciando o quão forte são os laços dessa língua com o território.

Não há quem desconheça a predominancia do tupi nas nossas denominações geographicas. As nossas montanhas, os nossos rios, as cidades como os simples povoados trazem geralmente nomes barbaros que o gentio, dominador outrora, lhes applicou, que os conquistadores respeitaram e que hoje são de todos preferidos, pois, não raro, se trocam, se substituem nomes portuguezes de antigas localidades, por outros de procedencia indigena, ás vezes lembrados ou compostos na occasião, ás vezes restaurados pelos amadores de coisas velhas e tradicionaes (SAMPAIO, 1901, p. 3).

\subsection{Portugueses: os (explor)colonizadores}

O início da colonização efetiva portuguesa no Brasil se deu a partir da implantação das Capitanias Hereditárias, objetivando estabelecer estratégias de controle, inicialmente, sobre o litoral brasileiro. A princípio, os portugueses não demonstraram interesse em ocupar ou explorar as terras localizadas no interior do Brasil, pois poderiam obter lucro no litoral com a extração da madeira pau-brasil, utilizando a mão de obra indígena, além de enfrentar índios hostis no interior.

A costa brasileira possuía, em geral, o solo fértil para o plantio da cana-de-açúcar e foi aí que os portugueses implantaram engenhos, com mão de obra escrava indígena e, logo a seguir, negra. Dias e Albuquerque (1979, p. 15) afirmam que o açúcar "acionaria o processo de colonização. A Coroa tomara a seu cargo a montagem de engenhos. Considerava-se que o açúcar podia representar a melhor maneira de conveniente e lucrativo povoamento". A preponderância da Coroa deu-se nas capitanias reais, havendo iniciativa de particulares em outras, como Pernambuco e São Vicente.

Até o século XIX, plantava-se cana-de-açúcar para fabrico do açúcar e aguardente no território catuense, produtos estes exportados para a Europa. Além disto, cultivava-se algodão, fumo e mandioca e criava-se gado bovino. Os engenhos e fazendas eram de propriedade de portugueses ou seus descendentes, já nascidos no Brasil. 


\subsection{Africanos: a mão de obra escrava}

Os escravos africanos chegaram às terras brasileiras a partir do século XVI e a escravidão continuou até a segunda metade do século XIX. A mão de obra dos escravizados destinava-se às fazendas de cana e café, às minas e ao trabalho doméstico. Conforme Moura (1992, p. 8), "a consolidação da economia colonial intensificou o tráfico de africanos para o Brasil, especialmente para o Nordeste, onde um tipo de agroindústria se concentrou e floresceu com o cultivo da cana-de-açúcar".

Nas terras catuenses, segundo Oliveira (2015, p. 29), "[...] a propriedade mais antiga a ser registrada nessa região foi o Engenho Pojuca (também conhecido como engenho Caboclo), já mencionado em 1757 pela nova divisão que criou a paróquia catuense". O registro desta propriedade seria um balizador no entendimento da demarcação e ocupação territorial do município de Catu.

Numa petição datada de 1721 e catalogada pela Fundação Biblioteca Nacional (1945, p. 181), o Engenho Pojuca é citado como "engenho de fazer açúcar" fundado "sôbre as terras e sítios da Pojuca".

Pode-se encontrar a espacialização do Engenho Pojuca em representações cartográficas do início do século XIX, nomeadamente na Planta geografica do que se tem melhor averiguado nas commarcas da Bahia, Sergipe do El Rey, parte das de Ilheos, e Jacobina com a direção da costa que vai do banco do Rio de $S$. Francisco athe os Rio das Contas (Figura 3), datada de 1801 e cartografada por Luís dos Santos Vilhena, comprovando assim a relevância daquele engenho para o território no qual estava inserido.

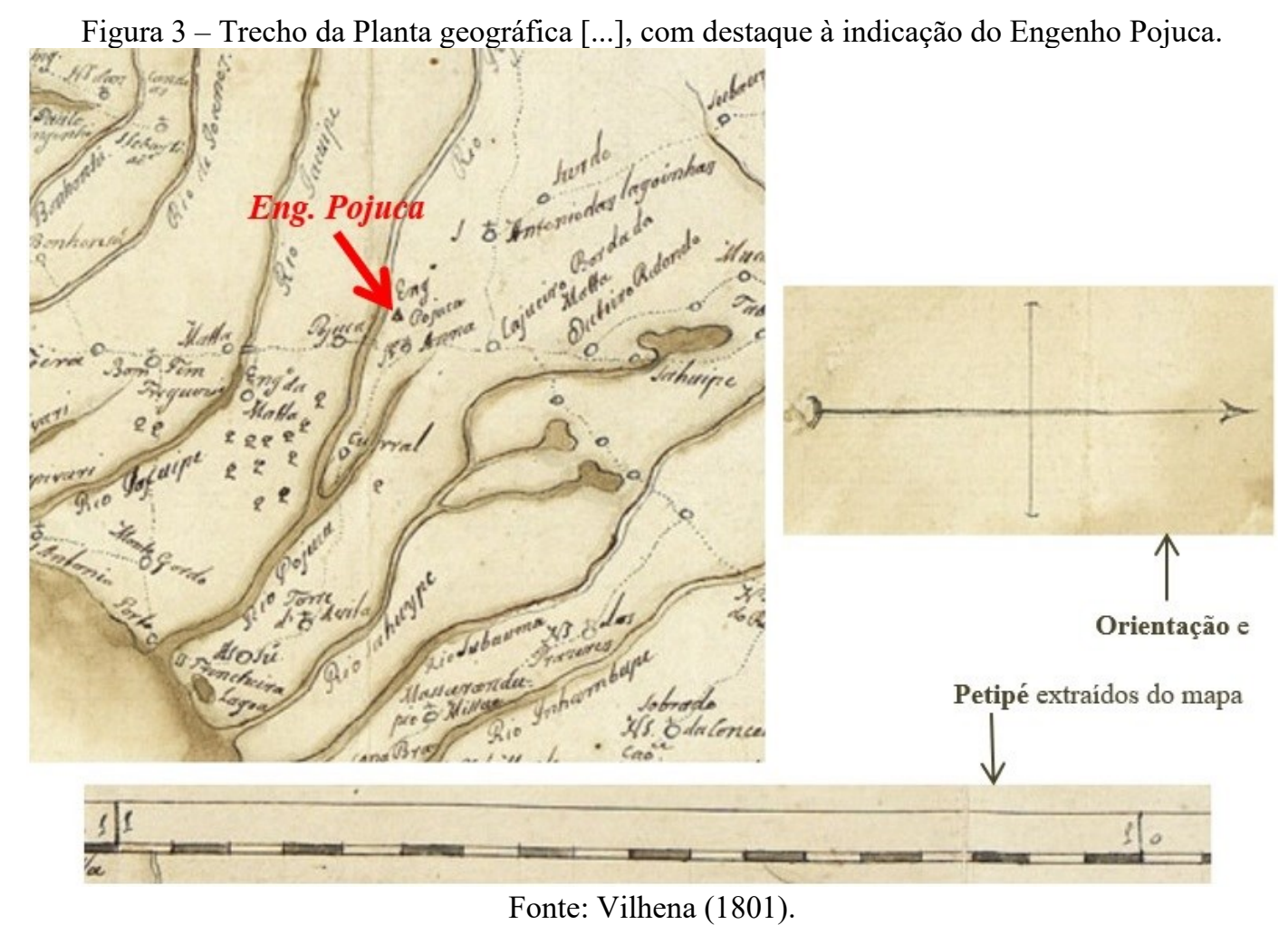

Conforme Moura (1992, p. 15), "o auge do escravismo coincide com o auge da exportação do açúcar para o mercado internacional”. Oliveira (2015, p. 30) relata que a ocupação de Catu se deu "[...] através da introdução do sistema plantation. Sistema produtor da monocultura agrícola de cana-de-açúcar para exportação, baseado na mão-de-obra escrava”.

\section{MATERIAIS E MÉTODOS}

Este estudo teve apoio principal nos mapas históricos, caracterizados como fonte primária da pesquisa documental, e a partir dos quais coletou-se a toponímia dos elementos hidrográficos. A sequência metodológica proposta para o trabalho é visualizada a seguir (Figura 4). 
Figura 4 - Sequência metodológica

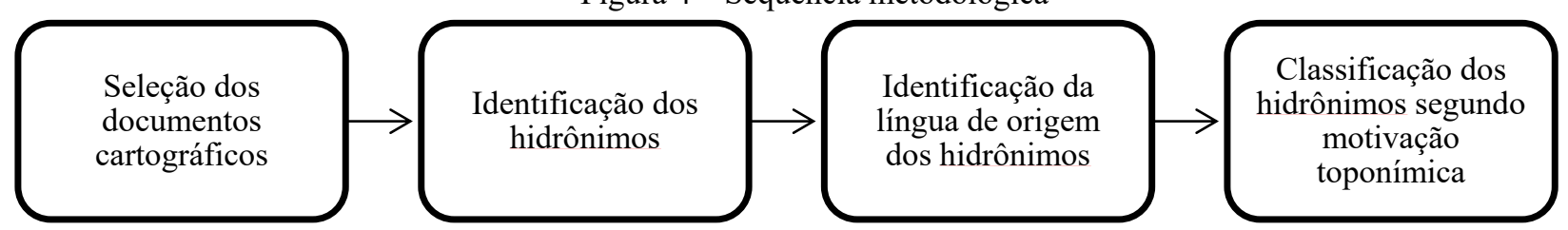

Fonte: Os autores (2021).

\subsection{Selecão dos documentos cartográficos}

Para a execução deste trabalho, buscaram-se documentos cartográficos de diferentes períodos referentes ao município de Catu-Bahia, em acervos históricos oficiais do Brasil, selecionando-se as representações a seguir:

a) Século XIX - Planta topographica da freguezia e municipio de Santa Anna do Catú da Comarca de Alagoinhas (Provincia da Bahia) (MENESES, 1888), disponível no formato JPG ${ }^{7}$ pela Fundação Biblioteca Nacional, Rio de Janeiro, Brasil (Figura 5). Relativamente à escala, a planta apresenta as seguintes informações: "escalla 1.000 braças" e "reduzido da metade de 1 cm para 100 braças". Para definição da escala, adequando a unidade de medida à utilizada nos outros documentos cartográficos selecionados, interpretou-se a informação textual existente no petipé, onde cada divisão (porção principal ou talão) tem $0,5 \mathrm{~cm}$ (mapa) $=100$ braças $=220 \mathrm{~m}$ (real). Assim, constatou-se que a escala da planta tem o valor, aproximado, de 1:44.000;

b) Século XX - Mapa do Município de Catú (LAGO, 1939), na escala 1:50.000 e disponível no formato JPG pelo Arquivo Nacional, Rio de Janeiro, Brasil (Figura 6);

c) Século XXI - Mapa Municipal de Catu-BA (IBGE, 2018), na escala 1:75.000, e obtida no sítio do IBGE (Figura 7) em Portable Document Format (PDF).

Figura 5 - Planta topographica da freguezia e municipio de Santa Anna do Catú da Comarca de Alagoinhas (Provincia da Bahia).

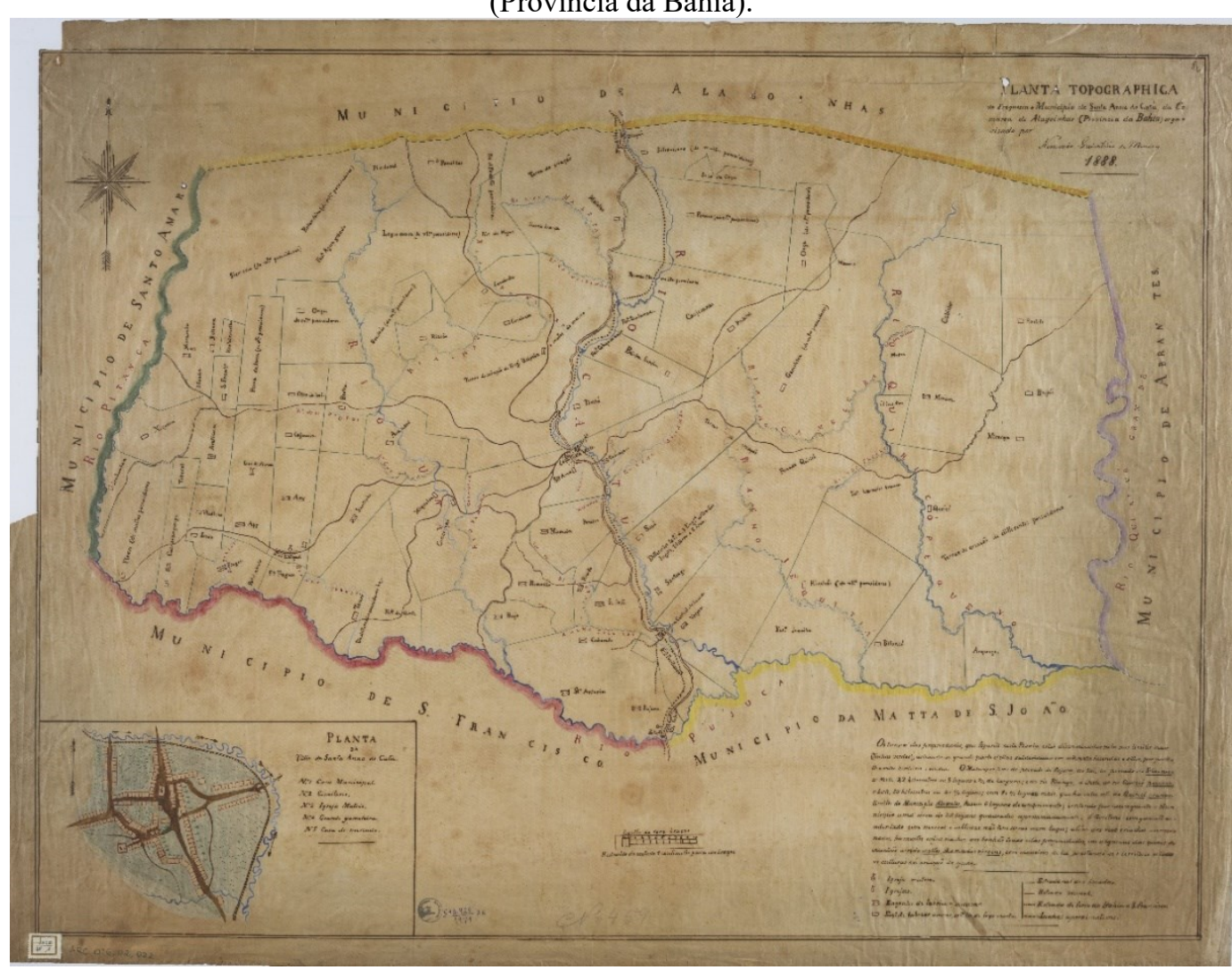

Fonte: Meneses (1888). 
Figura 6 - Mapa do município de Catú.

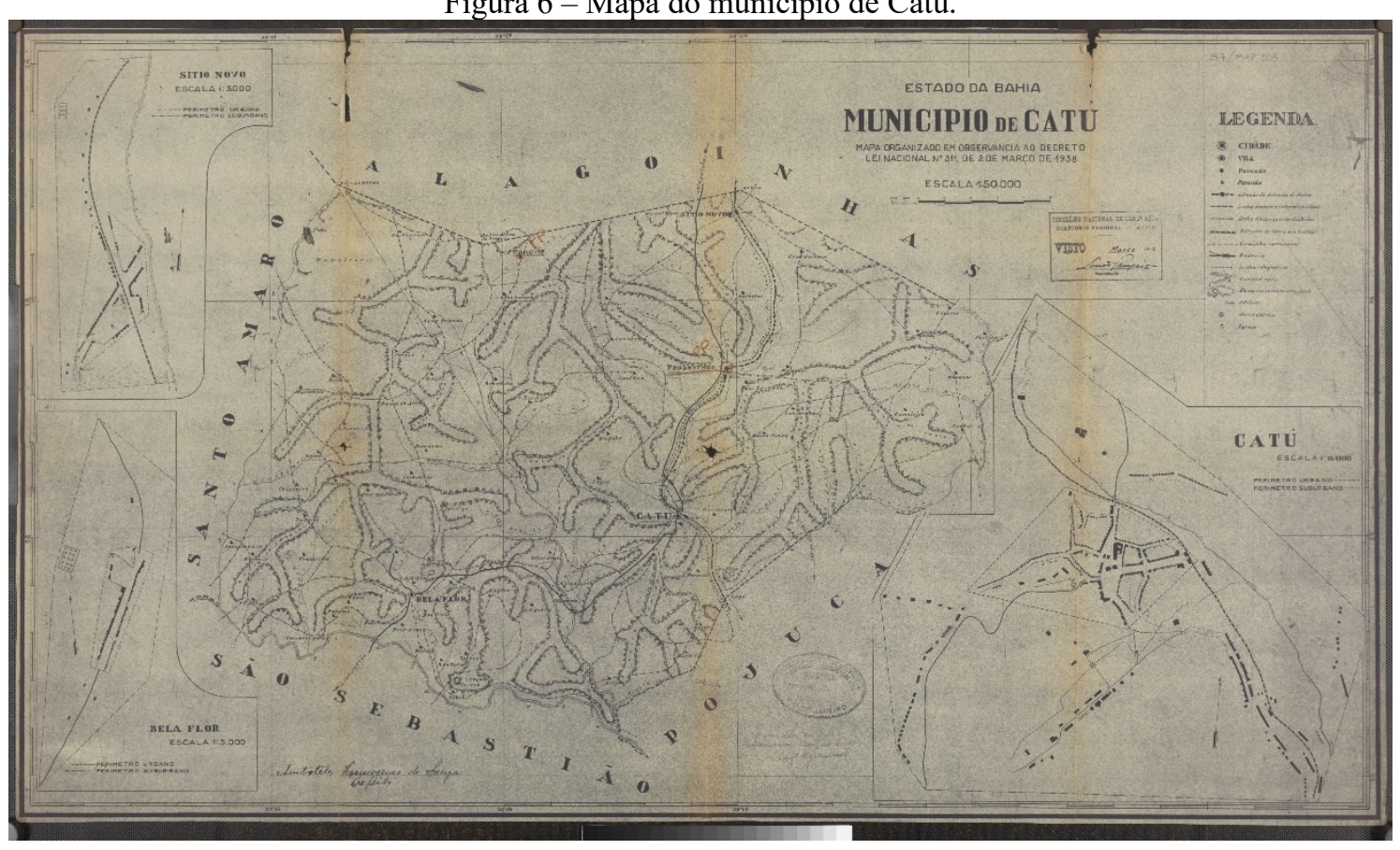

Fonte: Lago (1939).

Figura 7 - Mapa municipal de Catu-BA.

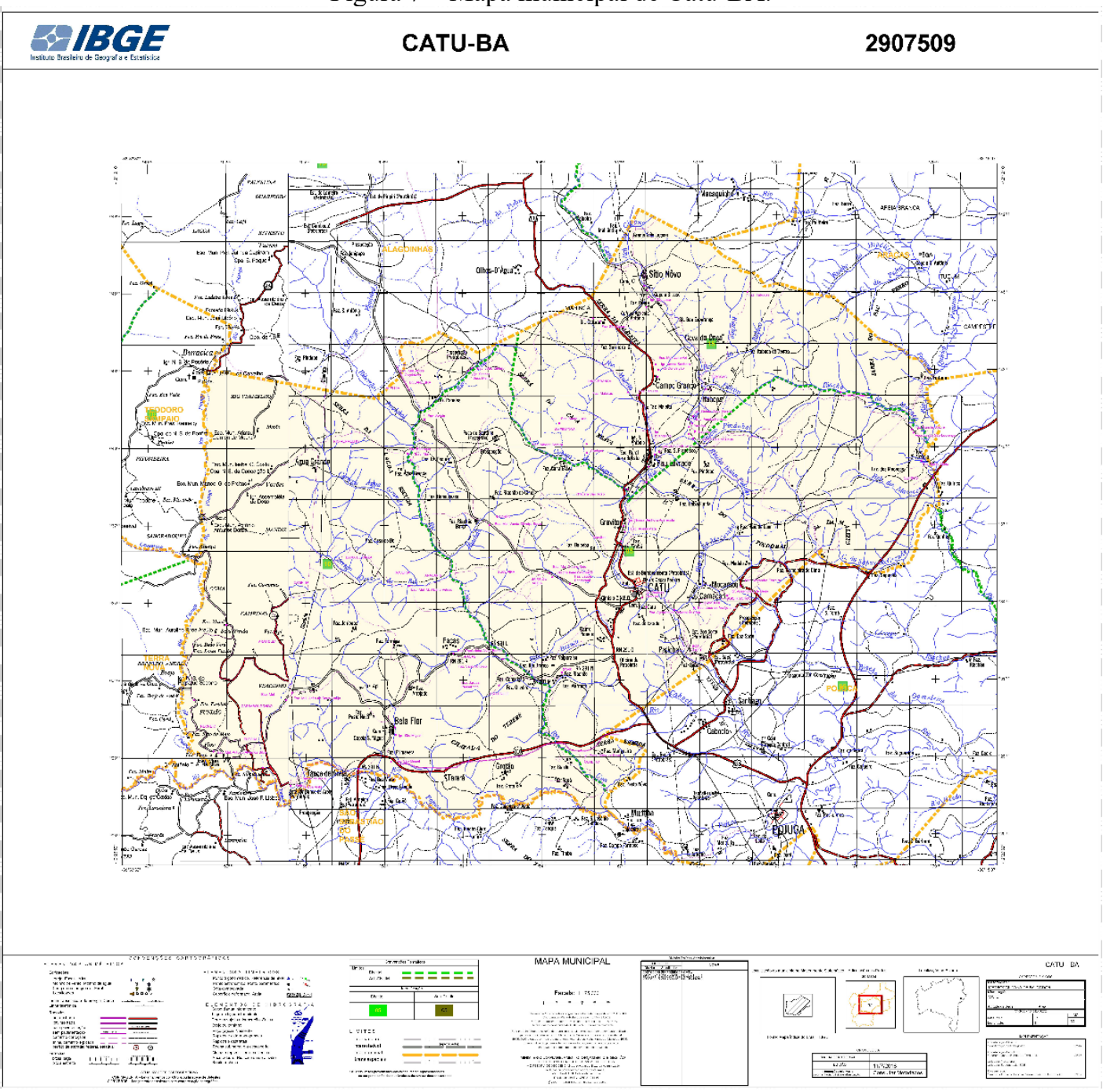

Fonte: IBGE (2018). 


\subsection{Identificação e classificação dos hidrônimos}

Nesta etapa, foram identificados os hidrônimos por comparação visual, pois os documentos cartográficos não estão georreferenciados. Na identificação, considerou-se também a posição geográfica análoga do elemento hidrográfico nos três documentos cartográficos, fator utilizado na verificação de alteração toponímica ou de curso d'água sem topônimo.

Vale destacar que a estrutura do hidrônimo é formada pelo termo genérico e termo específico (Figura 8), conforme referido por Castiglioni (2018).

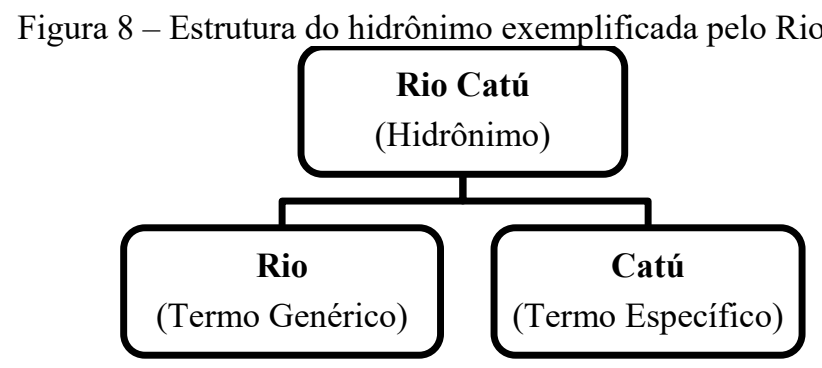

Fonte: Os autores (2021).

Quanto a origem linguística, os hidrônimos foram classificados como provenientes da língua portuguesa, língua indígena e outras línguas (especificamente de origem africana). Para este procedimento, foram buscados os significados em dicionários específicos das línguas apontadas.

\subsection{Motivação toponímica}

No presente trabalho, utilizou-se a taxonomia de natureza física e antropocultural proposta por Dick (1992) para justificar a motivação toponímica dos elementos hidrográficos. Em seu estudo Dick desenvolveu classes sistematizadoras dos motivos ou das fontes geradoras dos nomes de lugares, que caracterizam a motivação toponímica.

A partir desta classificação taxonômica, verificou-se a classe que mais motivou as denominações dos elementos hidrográficos para cada mapa analisado.

\section{RESULTADO E DISCUSSÃO}

A partir do quantitativo de hidrônimos identificados e classificados em cada documento cartográfico (Tabela 1), constatou-se que o mapa do século XX (1939) apresenta maior total de nomes dos elementos hidrográficos. Embora as escalas dos mapas sejam próximas em termos de valores numéricos (1:44.000, 1:50.000 e 1:75.000), notou-se que alguns cursos d'água não possuem denominação e/ou não estão representados graficamente. Deste modo, não foram contabilizados.

Tabela 1 - Quantidade de hidrônimos identificados e classificados por documento cartográfico.

\begin{tabular}{c|c|c}
\hline \multirow{2}{*}{ Documento cartográfico } & \multicolumn{2}{|c}{ Hidrônimos } \\
\cline { 2 - 3 } & Identificados & Classificados \\
\hline 1888 & 25 & 25 \\
1939 & 28 & 28 \\
2018 & 24 & 24 \\
\hline
\end{tabular}

Fonte: Os autores (2021).

As mudanças toponímicas ocorridas nos elementos hidrográficos do município de Catu (Quadro 1) ao longo do período estudado, sofreram alteração na grafia (Riacho Mucambo para Riacho Mocambo) e até mesmo foram renomeados (Ramela para Córrego Orobó, Riacho Gameleira para Córrego da Sapucaia Grande, Riacho Mucambo para Riacho Camassari e Rio do Negro para Rio Cabeça de Negro). Vale ressaltar que os elementos hidrográficos que não apresentam toponímia nas representações cartográficas foram caracterizados como Sem nome. 


\begin{tabular}{|l|l|l|}
\multicolumn{1}{|c|}{$\begin{array}{c}\text { Séc. XIX } \\
(\mathbf{1 8 8 8})\end{array}$} & \multicolumn{1}{c|}{$\begin{array}{c}\text { Quadro 1- Alteração toponímica. } \\
\text { Séc. XX } \\
(\mathbf{1 9 3 9 )}\end{array}$} & \multicolumn{1}{c|}{$\begin{array}{c}\text { Séc. XXI } \\
(\mathbf{2 0 1 8 )}\end{array}$} \\
\hline Ramela & Córrego Orobó & Sem nome \\
\hline Riacho Gameleira & Riacho Gameleira & Córrego da Sapucaia Grande \\
\hline Riacho Mucambo & Riacho Camassari & Riacho do Mocambo \\
\hline Riacho Tereré & Riacho São Miguel & Sem nome \\
\hline Rio do Negro & Rio Negro & Rio Cabeça de Negro \\
\hline Rio Quiricó Pequeno & Rio Quiricosinho & Rio Quiricó Pequeno \\
\hline
\end{tabular}

Fonte: Os autores (2021).

Um fato interessante é que na planta de 1888, o Rio Quiricó Grande e os Riachos Caboculo, das Mossas e Freire fazem parte do território catuense. Após desmembramentos ocorridos no município de Catu-Bahia, esses cursos d'água deixaram de fazer parte da rede hidrográfica local, fato que pode ser observado nos demais documentos cartográficos. No mapa de 1939, o Rio Quiricó Pequeno apresenta a nomenclatura Rio Quiricosinho e, no documento cartográfico de 2018, retoma o nome inicial. Outra referência toponímica ao Rio Quiricó Grande e Rio Quiricó Pequeno foi encontrada na Relação da Freguezia do Divino Espírito Santo do Sertão do Inhambupe de Cima, pelo Vigário encomendado Joaquim de Sant'Anna (ARQUIVO HISTÓRICO ULTRAMARINO, 1757), cujos rios são denominados de Quericó grande e Quericó merim, respectivamente.

Os resultados quanto a origem linguística dos hidrônimos são apresentados no Gráfico $1 \mathrm{em}$ valores absolutos e percentuais, de acordo com os documentos cartográficos analisados.

Gráfico 1 - Distribuição dos hidrônimos segundo a origem linguística.

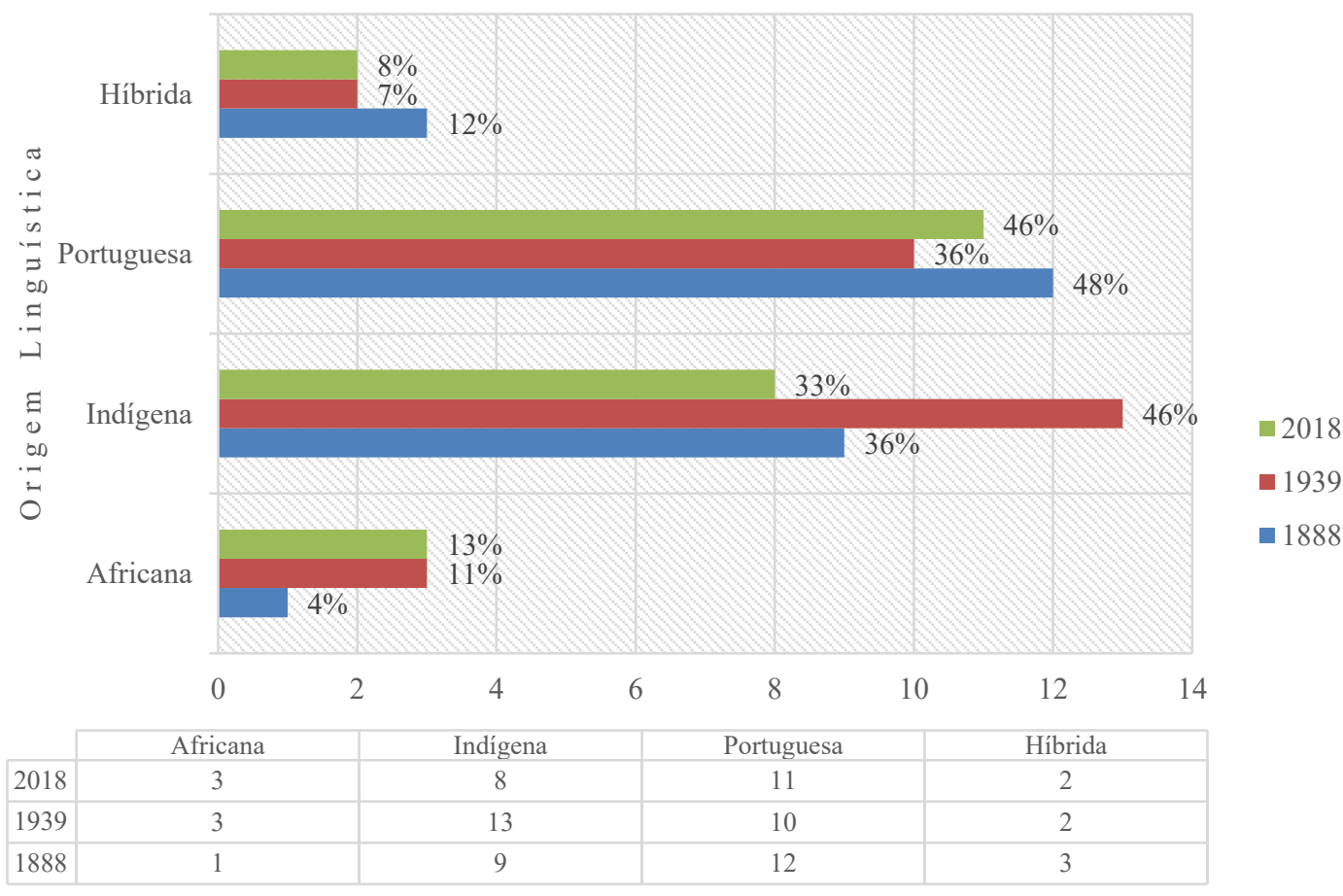

Total de Hidrônimos

Fonte: Os autores (2021).

Observa-se que nos documentos cartográficos datados de 1888 e 2018, há maior número de hidrônimos da língua portuguesa, seguido pelas denominações de origem linguística indígena. O mapa de 1939 contém aumento significativo nos nomes dos elementos hidrográficos de origem linguística indígena.

Cabe ressaltar que, existe apenas um caso de hidrônimo originário de outra língua, fazendo referência à africana, para o documento cartográfico de 1888. Trata-se do Riacho Mucambo, que no mapa de 1939 denomina-se Riacho Camassari (língua indígena), voltando à nomenclatura Riacho do Mocambo no documento cartográfico de 2018. Atenta-se ao significado do termo específico Mocambo (grafia encontrada 
no dicionário), consoante menciona Pinto (1832, p. 723): "Habitação, que fazem os pretos fugitivos nos matos, chamada por outro nome Quilombo”. Já no mapa de 1939, encontram-se os hidrônimos Córrego Cabanga, Córrego Mucambo e Riacho do Macaco, de origem africana. O termo específico Cabanga é definido como "um tipo de aguardente" (SAMPAIO, 2008, p. 256), e este elemento hidrográfico não está representado na planta de 1888, assim como não possui topônimo no mapa de 2018. O Córrego Mucambo não apresenta geometria nos documentos cartográficos de 1888 e 2018. O termo específico do Macaco é definido por Sampaio (1901, p. 137) como o "nome comum dos simios" e este curso d'água também está presente no mapa de 2018. Em se tratando do mapa de 2018, além dos elementos hidrográficos citados, há outro curso d'água com nomenclatura Riacho dos Macacos, o qual não aparece representado nos demais períodos analisados.

Os três documentos cartográficos apresentam ocorrência de hidrônimo híbrido, formado por palavras originárias de diversas línguas, visualizados a seguir (Tabela 2).

Tabela 2 - Hidrônimos híbridos.

\begin{tabular}{c|c|c}
\hline Documento cartográfico & Hidrônimo & Origem linguística \\
\hline \multirow{2}{*}{1888} & Rio Quiricó Grande & Africana + Portuguesa \\
& Rio Quiricó Pequeno & Africana + Portuguesa \\
& Riacho Cajoeirinho & Indígena + Portuguesa \\
\hline \multirow{2}{*}{1939} & Rio Quiricosinho & Africana + Portuguesa \\
& Riacho Cajueirinho & Indígena + Portuguesa \\
\hline \multirow{2}{*}{2018} & Rio Quiricó Pequeno & Africana + Portuguesa \\
& Córrego da Sapucaia Grande & Indígena + Portuguesa \\
\hline
\end{tabular}

Fonte: Os autores (2021).

A partir da classificação taxonômica dos hidrônimos, comparou-se o quantitativo da motivação toponímica para cada documento cartográfico analisado (Gráfico 2).

Gráfico 2 - Classificação taxonômica.

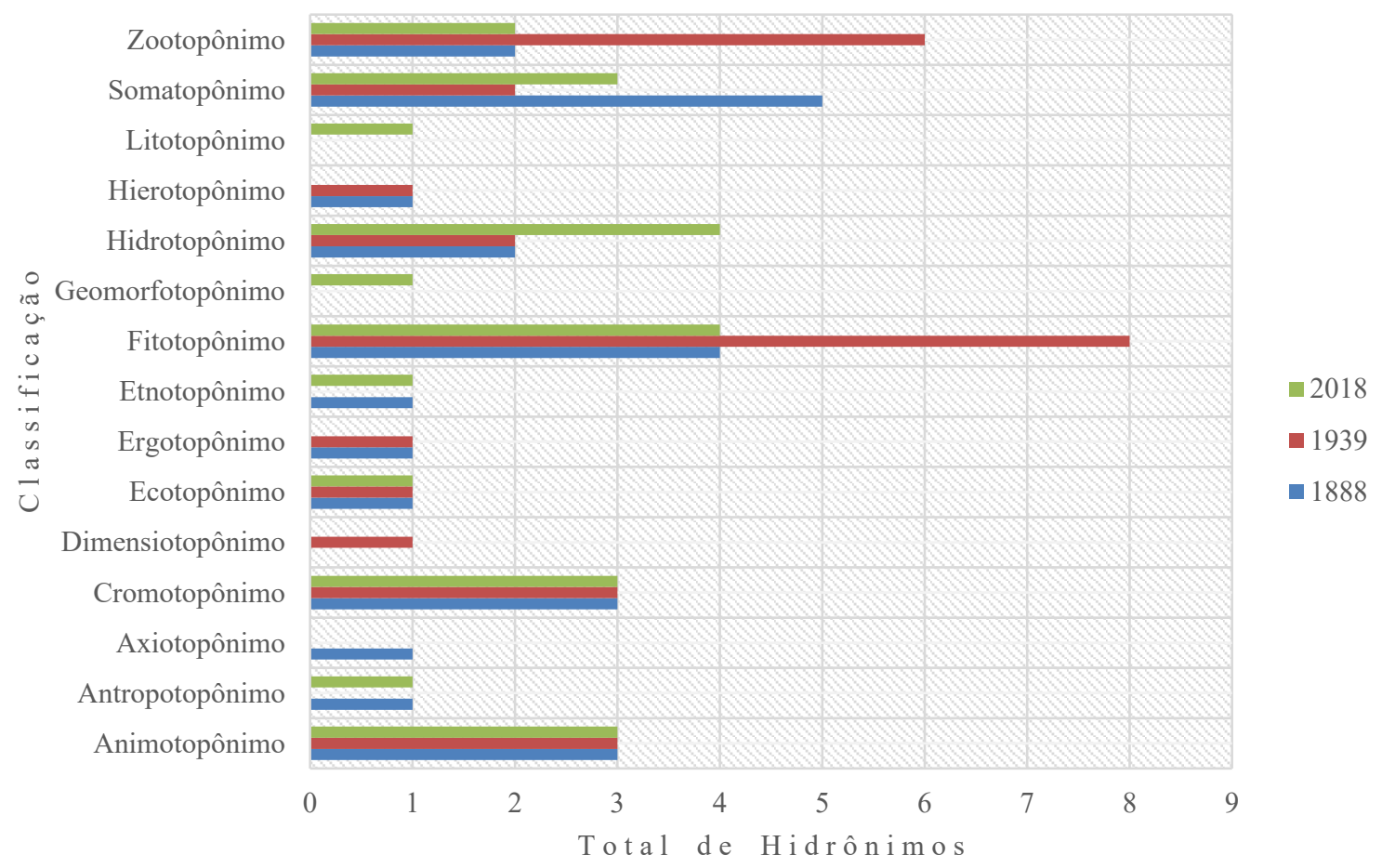

Fonte: Os autores (2021).

A título de conhecimento, a classificação taxonômica (cf. Gráfico 2) baseada na proposta por Dick (1992) é apresentada e descrita, segundo as classes de natureza física e antropocultural utilizadas neste trabalho (Quadro 2). 
Quadro 2 - Taxonomia de natureza física e antropocultural utilizada.

\begin{tabular}{|c|c|}
\hline \multicolumn{2}{|c|}{ Classificação taxonômica } \\
\hline Natureza Física & $\begin{array}{l}\text { Natureza Antropocultural } \\
\end{array}$ \\
\hline Cromotopônimos (escala cromática) & Animotopônimos (vida psíquica e cultura espiritual) \\
\hline Dimensiotopônimos (dimensões dos acidentes geográficos) & Antropotopônimos (nomes próprios individuais) \\
\hline Fitotopônimos (vegetais) & Axiotopônimos (títulos e dignidades que acompanham os nomes \\
\hline Geomorfotopônimos (formas topográficas) & próprios) \\
\hline Hidrotopônimos (acidentes hidrográficos) & Ecotopônimos (habitações de um modo geral) \\
\hline Litotopônimos (minerais e constituição do solo) & Ergotopônimos (elementos da cultura material) \\
\hline Zootopônimos (animais) & Etnotopônimos (elementos étnicos) \\
\hline & $\begin{array}{l}\text { Hierotopônimos (nomes sagrados, às efemeridades religiosas, aos } \\
\text { locais de culto) }\end{array}$ \\
\hline & $\begin{array}{l}\text { Somatopônimos (relação metafórica às partes do corpo humano ou } \\
\text { do animal) }\end{array}$ \\
\hline
\end{tabular}

Fonte: Adaptado de Dick (1992).

O documento cartográfico de 1888 denota a alusão às partes do corpo humano ou de animais como o maior elemento motivador das denominações hidrográficas, classificando-as como Somatopônimos. Riacho Osso do Boi, Ramela e Mãozinha são originários da língua portuguesa. Contudo, Rio Quiricó Grande e Rio Quiricó Pequeno são nomes híbridos (línguas africana e portuguesa). Ramela equivale a Remela, que corresponde ao "o humor amarello, que se ajunta nos lagrimaes dos olhos" (BLUTEAU; SILVA, 1789, p. 318). Para a designação Quiricó, uma possível derivação da palavra Quirica, a qual Castro (2001) traduz como hímen ou vulva.

A classe dos Fitotopônimos apresenta o maior quantitativo de hidrônimos existentes no mapa de 1939. Os originários de língua indígena são: Córrego Aratincum (Araticum), Córrego Timbó, Riacho Camassari, Riacho Jequitiá e Rio Pitanga. De origem portuguesa têm-se: Riacho Gameleira e Riacho Goma. Restando o Riacho Cajueirinho, que é composição híbrida (línguas indígena e portuguesa).

Os Fitotopônimos e Hidrotopônimos apresentam as maiores quantidades de hidrônimos no mapa de 2018. As denominações hidrográficas podem ser visualizadas a seguir (Quadro 3), onde também estão dispostos os hidrônimos extraídos dos documentos cartográficos, respeitando a equivalência entre os cursos d'água nos três mapas. A expressão Sem representação significa que o elemento hidrográfico não foi desenhado no mapa e Não pertence a Catu, o curso d'água não faz parte do perímetro municipal. No mesmo quadro, optou-se por discretizar a classificação taxonômica e origem linguística do mapa de 2018, por se tratar da representação cartográfica analisada com data mais recente, estando mais próxima da realidade atual da área de estudo.

Quadro 3 - Equivalência entre os hidrônimos dos mapas de 2018, 1939 e 1888.

Classificação taxonômica e origem linguística dos hidrônimos de 2018.

\begin{tabular}{|c|c|c|c|c|}
\hline $\begin{array}{c}\text { Hidrônimo } \\
2018\end{array}$ & $\begin{array}{c}\text { Taxonomia } \\
2018\end{array}$ & $\begin{array}{c}\text { Origem } \\
\text { linguística } \\
\mathbf{2 0 1 8} \\
\end{array}$ & $\begin{array}{c}\text { Hidrônimo } \\
1939\end{array}$ & $\begin{array}{c}\text { Hidrônimo } \\
1888\end{array}$ \\
\hline Rio Quiricó Pequeno & Somatopônimo & Híbrida & Rio Quiricosinho & Rio Quiricó Pequeno \\
\hline Rio Catú & Animotopônimo & Indígena & Rio Catú & Rio Catú \\
\hline Rio Una & Cromotopônimo & Indígena & Rio Una & Rio Una \\
\hline Rio Pitanga & Fitotopônimo & Indígena & Rio Pitanga & Rio Pitanga \\
\hline Rio Pojuca & Hidrotopônimo & Indígena & Rio Pojuca & Rio Pujuca \\
\hline Córrego da Sapucaia Grande & Fitotopônimo & Híbrida & Riacho Gameleira & Riacho Gameleira \\
\hline Riacho do Mocambo & Ecotopônimo & Africana & Riacho Camassari & Riacho Mucambo \\
\hline Rio Cabeça de Negro & Somatopônimo & Portuguesa & Rio Negro & Rio do Negro \\
\hline Riachão & Hidrotopônimo & Portuguesa & Riachão & Riachão \\
\hline Rio Maleita & Animotopônimo & Portuguesa & Riacho da Maleita & Riacho Maletas \\
\hline Rio Branco & Cromotopônimo & Portuguesa & Rio Branco & Rio Branco \\
\hline Córrego Osso de Boi & Somatopônimo & Portuguesa & Córrego Osso do Boi & Riacho Osso do Boi \\
\hline Córrego Fortuna & Animotopônimo & Portuguesa & Riacho Fortuna & Sem representação \\
\hline Riacho do Macaco & Zootopônimo & Africana & Riacho do Macaco & Sem representação \\
\hline Rio Una & Cromotopônimo & Indígena & Riacho Uruba & Sem nome \\
\hline Córrego Água Grande & Hidrotopônimo & Portuguesa & Sem nome & Sem representação \\
\hline Ribeirão Pindobal & Fitotopônimo & Indígena & Sem nome & Sem nome \\
\hline Riacho da Itaboca & Litotopônimo & Indígena & Sem representação & Sem representação \\
\hline Riacho do Cigano & Etnotopônimo & Portuguesa & Sem representação & Sem representação \\
\hline Córrego Faleiro & Antropotopônimo & Portuguesa & Sem representação & Sem representação \\
\hline
\end{tabular}




\begin{tabular}{|c|c|c|c|c|}
\hline $\begin{array}{c}\text { Hidrônimo } \\
2018\end{array}$ & $\begin{array}{c}\text { Taxonomia } \\
2018\end{array}$ & $\begin{array}{c}\text { Origem } \\
\text { linguística } \\
\mathbf{2 0 1 8}\end{array}$ & $\begin{array}{c}\text { Hidrônimo } \\
1939\end{array}$ & $\begin{array}{c}\text { Hidrônimo } \\
1888\end{array}$ \\
\hline Riacho Baixa Funda & Geomorfotopônimo & Portuguesa & Sem representação & Sem representação \\
\hline Riacho dos Macacos & Zootopônimo & Africana & Sem representação & Sem representação \\
\hline Riacho Pindobal & Fitotopônimo & Indígena & Sem nome & Sem representação \\
\hline Riachão & Hidrotopônimo & Portuguesa & Sem representação & Sem representação \\
\hline Sem nome & - & - & Riacho Jequitiá & Riacho Jequitiá \\
\hline Sem nome & - & - & Córrego Orobó & Ramela \\
\hline Sem nome & - & - & Córrego Capavira & Capavira \\
\hline Sem nome & - & - & Riacho Cajueirinho & Riacho Cajoeirinho \\
\hline Sem nome & - & - & Riacho Guariba & Riacho Guariba \\
\hline Sem nome & - & - & Riacho São Miguel & Riacho Tereré \\
\hline Sem nome & - & - & Riacho do Meio & Sem representação \\
\hline Sem representação & - & - & Riacho Goma & Sem representação \\
\hline Sem nome & - & - & Córrego Aratincum & Sem representação \\
\hline Sem nome & - & - & Córrego Cabanga & Sem representação \\
\hline Sem nome & - & - & Riacho Muritiba & Sem representação \\
\hline Sem nome & - & - & Córrego Timbó & Sem representação \\
\hline Sem representação & - & - & Córrego Mucambo & Sem representação \\
\hline Não pertence a Catu & - & - & Não pertence a Catu & Rio Quiricó Grande \\
\hline Não pertence a Catu & - & - & Não pertence a Catu & Riacho Freire \\
\hline Não pertence a Catu & - & - & Não pertence a Catu & Mãozinha \\
\hline Não pertence a Catu & - & - & Não pertence a Catu & Riacho Caboculo \\
\hline Sem nome & - & - & Sem representação & Riacho Remedio \\
\hline Não pertence a Catu & - & - & Não pertence a Catu & Riacho das Mossas \\
\hline Sem nome & - & - & Sem nome & Riacho Fragozo \\
\hline
\end{tabular}

Fonte: Os autores (2021).

Ayrosa (1933, p. 35) descreve o ato de nomear os lugares: "[...] as denominações geographicas, $\hat{a}$ dos animaes, plantas etc., são rigorosamente descriptivas, isto é, traduzem aspectos notaveis dos lugares; habitos, feitios ou vozes dos animaes; cheiro, côr ou propriedades das plantas e fructos".

Assim, os cursos d'água eram nomeados de acordo com os elementos presentes nos espaços ocupados e, no território catuense, prevalecem hidrônimos de origem linguística indígena e portuguesa, sendo os vegetais os principais fatores motivacionais para tais denominações.

A partir dos documentos cartográficos históricos, observa-se que a cidade, a vila, os povoados e as fazendas foram instaladas próximas aos elementos hidrográficos. Ainda um aspecto de merecido destaque é que as fazendas, na sua maioria, foram nomeadas conforme a denominação do rio, riacho ou córrego, como por exemplo Fazenda Goma, Fazenda Maleita, Fazenda Mocambo, Fazenda Pindobal, Fazenda Riachão, entre outras. Isto denota a influência dos hidrônimos no processo de formação do território catuense e remete-se a afirmação de Dutra, Dargel e Silva (2014, p. 22) "que o hidrônimo serve como fonte de localização espacial e, além disso, como elemento a motivar novos signos toponímicos".

\section{CONCLUSÃO}

O estudo dos hidrônimos procura associar estes nomes com a origem da população e com as diferentes fases da ocupação e colonização do território.

Através de documentos da cartografia histórica, pode-se identificar os nomes dos lugares e acompanhar as variações ocorridas ao longo do tempo. No município de Catu-Bahia, Brasil, nota-se o predomínio de hidrônimos oriundos das línguas indígena e portuguesa, embora o território catuense tenha sido espaço para engenhos de açúcar no período colonial brasileiro, com grande mão de obra escrava proveniente da África. O estudo dos hidrônimos de Catu-Bahia comprova a tendência de natureza física para nomes dos elementos hidrográficos, particularmente os Fitotopônimos. Baseando-se na comparação entre os documentos, constatou-se que, em geral, as denominações originalmente indígenas não sofreram alteração toponímica para outra língua (exceto Riacho Tereré para Riacho São Miguel), preservando assim a essência primitiva dos hidrônimos catuenses.

Os mapas e planta analisados neste trabalho proporcionaram visualização da configuração espacial dos acidentes naturais e culturais do período em que foram cartografados. Considerando este aspecto, comprova- 
se que componentes da formação territorial, tais como cidade, vila, povoados e fazendas instalaram-se próximos aos elementos hidrográficos e, alguns, assumiram as nomenclaturas destes, dada a importância da hidrografia para a população.

\section{Contribuição dos Autores}

A autora Adriana Andrade Arnaut contribuiu com a conceptualização, investigação, metodologia, análise formal, visualização dos dados, redação e edição do texto. O autor Luciano Lourenço contribuiu com a orientação e revisão geral do trabalho.

\section{Conflitos de Interesse}

Os autores declaram que não há conflito de interesse.

\section{Referências}

ARQUIVO HISTÓRICO ULTRAMARINO. Conselho Ultramarino. Relação da Freguezia do Divino Espírito Santo do Sertão do Inhambupe de Cima, pelo Vigario encommendado Joaquim de Sant'Anna. Caixa 15/Doc. No 2714. Brasil-Baía, 1757.

AYROSA, P. Primeiras noções de tupi. São Paulo: s.ed. [autor?], 1933. Disponível em: $<$ http://etnolinguistica.wikidot.com/biblio:ayrosa-1933-primeiras>. Acesso em: 31 out. 2019.

BARBOSA, A. L. Pequeno vocabulário Tupi-Português. Rio de Janeiro: Livraria São José, 1951. Disponível em: <http://www.etnolinguistica.org > . Acesso em: 1 mai. 2019.

BLAEU, W. J. Novus Brasiliae Tipus. Amstelodami [Holanda]: Guijelmus Blaeuw execudit, [1631?]. Dimensões 38 x 49,1 cm em f. 45 x $55 \mathrm{~cm}$. Escala gráfica em milhas germânicas comuns [= 5,5 cm.] e milhas gaulesas comuns $\left[\begin{array}{lllll}= & 5 & \mathrm{~cm} .\end{array}\right]$ Disponível em: $<$ http://objdigital.bn.br/acervo_digital/div_cartografia/cart164712/art164712.jpg>. Acesso em: 14 nov. 2019.

BLUTEAU, R; SILVA, A. de M. Diccionario da lingua portuguesa. (Volume 2: L - Z). Lisboa: Officina de Simão Thaddeo Ferreira, 1789. Disponível em: $<$ https://digital.bbm.usp.br/handle/bbm/5413>. Acesso em: 1 nov. 2019.

CARDIM, F. Do Principio e Origem dos Indios do Brazil e seus Costumes, Adoração e Ceremonias. Rio de Janeiro: Typographia da Gazeta de Noticias, 1881. Disponível em: $<$ https://digital.bbm.usp.br $>$. Acesso em: 16 mai. 2019.

CASTIGLiOni, A. C. Verbete toponímico: microestruturas para hidrônimos. Revista de Estudos da Linguagem, Belo Horizonte, v. 26, n. 3, p. 1095-1122, Mar 2018. DOI. 10.17851/2237-2083.26.3.10951122 .

CASTRO, Y. P. de. Falares africanos na Bahia: um vocabulário afro-brasileiro. 2.ed. Rio de Janeiro: Academia Brasileira de Letras, 2001.

DiAs, M. N.; AlbuQUerQue, L. de. Natureza e estatuto da Capitania do Brasil. Lisboa: Junta de Investigações Científicas do Ultramar, 1979.

DICK, M. V. P. A. Toponímia e Antroponímia no Brasil. Coletânea de Estudos. 3.ed. São Paulo: USP, 1992.

DUTRA, N. A. S.; DARGEL, A. P. T. P.; SILVA, C. A. N. A inter-relação hidronímia e toponímia: um estudo de caso. Revista Ave Palavra, Alto Araguaia, n. 18, Dez 2014. Disponível em: $<$ http://www2.unemat.br/avepalavra/EDICOES/18/Arquivos/DUTRADARGELSILVA.pdf $>$. Acesso em: 20 out. 2019.

FERRO, G. Sociedade humana e ambiente, no tempo: temas e problemas de geografia histórica. [S.I.]: Fundação Calouste Gulbenkian, 1979.

FUNDAÇÃO BIBLIOTECA NACIONAL. Documentos Historicos (RJ) - 1928 a 2012. Ano 1945, Edição 
00069, 26-5-1721.

INSTITUTO BRASILEIRO DE GEOGRAFIA E ESTATÍSTICA (IBGE). Mapa Municipal de Catu. Rio de Janeiro: $\quad$ IBGE, 2018. Escala 1:75.000. Disponível em: $<\mathrm{ftp}$ //geoftp.ibge.gov.br/cartas_e_mapas/mapas_municipais/estimativas_populacionais/2018/BA/catu_2 018_v1.pdf $>$. Acesso em: 27 out. 2019.

INSTITUTO BRASILEIRO DE GEOGRAFIA E ESTATÍSTICA (IBGE). Nomes Geográficos do Brasil. Normas Técnicas para Revisão de Nomes Geográficos. Rio de Janeiro, 2011. Disponível em: $<$ http://www.ngb.ibge.gov.br/App_Doc/(APOSTILA_CURSO_NORMAS_T_311CNICAS_REVIS_303 O_NG_REVISADA4_27.10).pdf $>$. Acesso em: 9 fev. 2016.

ISQUERDO, A. N.; DICK, M. V. P. A. Da hidronímia à toponímia: interfaces histórico-culturais. In: SIMPÓSIO NACIONAL DE ESTUDOS FILOLÓGICOS E LINGUÍSTICOS, 5, 2013, Campo Grande. Resumos... Campo Grande: CIFEFIL, 2013. p. 40-41. Disponível em: $<$ http://www.filologia.org.br/v_sinefil/_livro_resumos.pdf>. Acesso em: 13 abr. 2021.

LAGO, J. L. B. Estado da Bahia - município de Catú. [S.I.: s.n.], 1939. Mapa organizado em observância ao Decreto Lei Nacional No 311, de 2 de março de 1938, dimensões $104 \mathrm{~cm}$ x $61 \mathrm{~cm}$. Escala 1:50.000.

LIND, I. De Portugal ao Brasil: um pequeno estudo de toponímia brasileira. Lisboa: Casa Portuguesa, 1963.

MENESES, N. Q. Planta topografica da freguezia e municipio de Santa Anna do Catú da Comarca de Alagoinhas (Provincia da Bahia). [S.I.: s.n], 1888, dimensões 65,8 x 87,1 cm em f. 70 x 91,7 cm. Escala gráfica de 100 braças $[=5,6 \mathrm{~cm}]$ reduzida da metade de 1 centímetro para 100 braças.

MENEZES, P. M. L.; SANTOS, C. J. B.; SANTOS, B. C. P. Geonímia e a Cartografia Histórica: um estudo sobre os nomes da hidrografia fluminense. In: III Simpósio Brasileiro de Ciências Geodésicas e Tecnologias da Geoinformação. 2010, Recife. Anais... Recife: Universidade Federal de Pernambuco. Departamento de Engenharia Cartográfica, 2010. p. 1-8. Disponível em: $<$ https://www3.ufpe.br/cgtg/SIMGEOIII/IIISIMGEO_CD/artigos/CartografiaeSIG/Cartografia/A_176.p df $>$. Acesso em: 19 out. 2019.

MOURA, C. História do Negro Brasileiro. 2.ed. São Paulo: Editora Ática, 1992.

OLIVEIRA, M. S. A Imperial Vila de Santana do Catu - histórias de uma comunidade escravista no Recôncavo Baiano. 1.ed. Salvador: Quarteto Editora, 2015.

PINTO, L. M. da S. Diccionario da lingua brasileira. Ouro Preto: Typographia de Silva, 1832. Disponível em: $<$ https://digital.bbm.usp.br/handle/bbm/5414>. Acesso em: 22 abr. 2020.

SAMPAIO, T. O Tupi na Geographia Nacional. São Paulo: Typ. da Casa Eclectica, 1901. Disponível em: $<$ http://biblio.etnolinguistica.org/sampaio_1901_tupi>. Acesso em: 31 out. 2019.

SAMPAIO, N. A. de F. Por uma poética da voz africana: transculturações em romances e contos africanos e em cantos afro-brasileiros. 334 f. Dissertação (Mestrado em Letras) - Faculdade de Letras, Universidade Federal de Minas Gerais, Belo Horizonte, 2008.

SILVA, C. Os principais hidrônimos da cidade de Pires do Rio-GO e suas motivações de nomeação. Revista Letras Raras, Campina Grande, v. 8, n. 1, p. 7-22, Mar 2019. DOI. 10.35572/rlr.v811.1138.

VILHENA, L. dos S. Planta geografica do que se tem melhor averiguado nas commarcas da Bahia, Sergipe do El Rey, parte das de Ilheos, e Jacobina com a direção da costa que vai do banco do Rio de S. Francisco athe os Rio das Contas. 1801. 1 mapa mss, il. Col. Disponível em: $<$ http://objdigital.bn.br/acervo_digital/div_manuscritos/mss1304801_34/mss1304806_10.jpg >. Acesso em: 29 abr. 2020.

YEGINBAYEVA, A.; SAPAROV, K.; ARALBEKOVA, M.; ATASOY, E.; KIZILÇAOĞLU, A.; WENDT, J. A. The role of GIS mapping method in toponymy research. Uludağ Üniversitesi Fen Edebiyat Fakültesi Sosyal Bilimler Dergisi, Bursa, v. 19, n. 30, p. 11-18, Jan 2016. DOI. 10.21550/sosbilder.290455. 


\section{Biografia do autor principal}

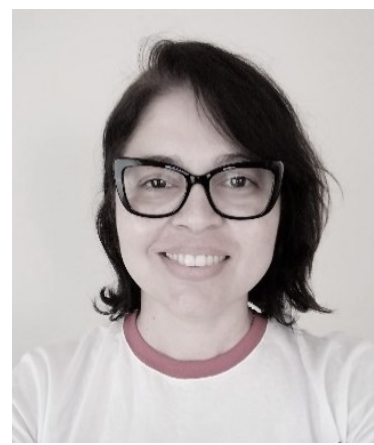

Adriana Andrade Arnaut nasceu em Camaçari, Bahia. Graduada em Engenharia de Agrimensura pela Escola de Engenharia de Agrimensura (Bahia), especialista em Geotecnologias pela Escola de Engenharia de Agrimensura (Bahia) e mestre em Engenharia Cartográfica pelo Instituto Militar de Engenharia (Rio de Janeiro). Possui experiência nas áreas de Educação e Geotecnologias, com atuação em Cartografia Básica e Digital, Sistemas de Posicionamento por Satélites (GNSS/GPS) e Sistema de Informação Geográfica (SIG). Atualmente é professora do Instituto Federal de Educação, Ciência e Tecnologia Baiano, Campus Catu e doutoranda em Geografia na Universidade de Coimbra (Portugal), com pesquisa voltada à Cartografia Histórica. 